\title{
Fungal-bacterial dynamics and their contribution to terrigenous carbon turnover in relation to organic matter quality
}

\author{
Jenny Fabian ${ }^{1}$, Sanja Zlatanovic ${ }^{2}$, Michael Mutz ${ }^{2}$ and Katrin Premke ${ }^{1}$ \\ ${ }^{1}$ Department Chemical Analytics and Biogeochemistry, Leibniz-Institute of Freshwater Ecology and Inland \\ Fisheries (IGB), Berlin, Germany and ${ }^{2}$ Department of Freshwater Conservation, BTU-Cottbus Senftenberg, Bad \\ Saarow, Germany
}

\begin{abstract}
Ecological functions of fungal and bacterial decomposers vary with environmental conditions. However, the response of these decomposers to particulate organic matter (POM) quality, which varies widely in aquatic ecosystems, remains poorly understood. Here we investigated how POM pools of substrates of different qualities determine the relative contributions of aquatic fungi and bacteria to terrigenous carbon (C) turnover. To this end, surface sediments were incubated with different POM pools of algae and/or leaf litter. ${ }^{13} \mathrm{C}$ stable-isotope measurements of $\mathrm{C}$ mineralization were combined with phospholipid analysis to link the metabolic activities and substrate preferences of fungal and bacterial heterotrophs to dynamics in their abundance. We found that the presence of labile POM greatly affected the dominance of bacteria over fungi within the degrader communities and stimulated the decomposition of beech litter primarily through an increase in metabolic activity. Our data indicated that fungi primarily contribute to terrigenous $\mathbf{C}$ turnover by providing litter $\mathbf{C}$ for the microbial loop, whereas bacteria determine whether the supplied $C$ substrate is assimilated into biomass or recycled back into the atmosphere in relation to phosphate availability. Thus, this study provides a better understanding of the role of fungi and bacteria in terrestrial-aquatic $\mathrm{C}$ cycling in relation to environmental conditions.
\end{abstract}

The ISME Journal (2017) 11, 415-425; doi:10.1038/ismej.2016.131; published online 16 December 2016

\section{Introduction}

Freshwater ecosystems receive and process large amounts of terrigenous carbon (C) (Cole et al., 2007), often in the form of leaf litter (Fisher and Likens, 1973; Tank et al., 2010). Herein, microbial heterotrophs greatly contribute to terrestrial-aquatic C cycling (Battin et al., 2008; Ward et al., 2013). The terrigenous subsidy is either assimilated into biomass, providing energy and nutrients for higher trophic levels of the food web (Attermeyer et al., 2013; Marcarelli et al., 2011), or mineralized to $\mathrm{CO}_{2}$, contributing substantially to global biogeochemical fluxes (Bardgett et al., 2008; Rousk and Bengtson, 2014; Battin et al., 2016).

Notably, the particulate forms of terrigenous $\mathrm{C}$ have a highly complex, aromatic chemical structure and large $\mathrm{C}$ to nutrient stoichiometry (McGroddy et al., 2004; Lau et al., 2008); they are

Correspondence: J Fabian, Department Chemical Analytics and Biogeochemistry, Leibniz-Institute of Freshwater Ecology and Inland Fisheries (IGB), Berlin, 12587 Germany.

E-mail: fabian@igb-berlin.de

Received 15 April 2016; revised 24 July 2016; accepted 5 August 2016; published online 16 December 2016 therefore considered quite refractory toward microbial decomposition (Kleber et al., 2011; Attermeyer et al., 2014). Yet, modern research implies that environmental factors, rather than the chemical structure, control the microbial decomposition of terrigenous particulate organic matter (POM). Microbial communities respond rapidly to changes in their environment in two ways, either through variation in the species composition and/or metabolic activity (Comte and del Giorgio, 2011), both of which shape their performance in terrigenous POM cycling. Therefore, identifying drivers for the microbial turnover of terrigenous POM at the community level is fundamental to understand the role of aquatic decomposers in terrestrial-aquatic C cycling (Rousk and Bengtson, 2014).

Bacterial and fungal heterotrophs dominate microbial decomposer communities (Hieber and Gessner, 2002). However, these groups are phylogenetically distant and differ in their metabolic requirements and cellular capabilities (Mille-Lindblom and Tranvik, 2003). The typical filamentous structure of most fungi facilitates their penetration into particulate substrates, whereas bacteria are suspended in or attached to substrates (Baldy et al., 1995). Fungal decomposers also have a lower metabolic nutrient 
demand (reviewed in Danger et al., 2016) and wider enzymatic capabilities than bacteria, which allow them to mineralize low-quality substrates like particulate leaf litter (Güsewell and Gessner, 2009). However, bacteria are characterized by shorter turnover and higher metabolic activities (Bardgett et al., 1999; Attermeyer et al., 2013). Consequently, fungi and bacteria occupy different functional niches in POM decomposition: fungi act as primary degraders of particulate, predominately terrigenous $\mathrm{C}$ and bacteria act as rapid recyclers of simply structured nutrient-rich organic matter (OM) compounds (Gessner et al., 2007; Krauss et al., 2011).

The relative abundance of fungi and bacteria varies among different POM pools (Findlay et al., 2002), which can have profound effects on ecosystem functioning (Rinnan and Bååth, 2009; Strickland et al., 2009) with regard to their functional niche in the mineralization of terrigenous OM (De Graaff et al., 2010). However, studies simultaneously evaluating the different ecological roles of both fungi and bacteria are scarce, especially in the relation to environmental factors (Schneider et al., 2012), and such investigation is mainly limited to soil studies (Rousk and Bååth, 2007). Moreover, the contribution of fungi and bacteria to OM degradation is not solely a function of their abundance, but of their metabolic activity that varies with changes in POM quality (Meidute et al., 2008; Brandstätter et al., 2013).

The availability of leaf litter for microbial degradation increases in the presence of algae-derived OM (Danger et al., 2013; Ward et al., 2016) denoting that energy-rich $\mathrm{OM}$ aid in the microorganisms' metabolic capabilities to degrade more complex, lowquality C (Kuehn et al., 2014). Yet, whether this newly available substrate is assimilated or mineralized seems to be determined by the phosphate (P) availability (Rier et al., 2014). Hence, this study is aimed at deliberately exploring how POM pools of substrates of different qualities, such as algae and leaf litter, determine the relative contributions of fungal and bacterial groups to POM degradation. We hypothesized that (i) the quality of POM pools determines the microbial performance in POM decomposition, (ii) algal POM stimulates the metabolic activity of fungi and bacteria toward leaf litter POM decomposition rather than their abundance and (iii) the contribution of bacteria to terrigenous $\mathrm{C}$ turnover varies with the C:P stoichiometry of algal substrates.

Using a stable-isotope approach, we incubated natural streambed sediments with different POM pools. These pools were generated through the combination of high-quality (algal POM) and lowquality terrigenous (litter POM) substrates that were ${ }^{13} \mathrm{C}$-labeled to directly trace their microbial mineralization through continuous measurements of ${ }^{13} \mathrm{CO}_{2}$ : total $\mathrm{CO}_{2}$ production. We further combined microbial respiration measurements with the analysis of aquatic phospholipid-derived fatty acid biomarkers (PLFA) to link microbial activities to microbial community dynamics for fungi and bacteria. The combination of PLFA biomarker analysis with stable-isotope analysis further provides information on the acquisition of different substrates distinct in their isotopic signature. Thus, we were able to directly determine group-specific changes in substrate utilization (Neufeld et al., 2007) in relation to the substrate composition of the applied POM pools.

Consequently, the results from this study provide important implications for our understanding of terrigenous $\mathrm{C}$ transformation in aquatic ecosystems and thus contribute to a better understanding of the role of microbial decomposers in terrestrial-aquatic C cycling.

\section{Materials and methods}

\section{Experimental procedures}

Microbial sediment communities were incubated for 46 days under stable climate conditions (in the dark at $20^{\circ} \mathrm{C}$ ) together with POM pools that differed in their quality composition (Figure 1a). Therefore, natural sandy sediments were incubated in gastight sealed cylinders (acrylic glass, $d=11.5 \mathrm{~cm}$, $h=20 \mathrm{~cm}$ ) with artificial water (modified after Lehman, 1980, containing $20 \mathrm{mg} \mathrm{CaCl}_{2} \mathrm{l}^{-1}, 15 \mathrm{mg}$ $\mathrm{MgSO}_{4} \cdot 7 \mathrm{H}_{2} \mathrm{O} \mathrm{l}^{-1}, 20 \mathrm{mg} \mathrm{NaHCO} \mathrm{l}^{-1}$ and $20 \mathrm{\mu ll}^{-1}$ SL10 solution of trace elements mixed and autoclaved in bi-distilled water, without $\mathrm{PO}_{4}^{-3}$ or $\mathrm{NO}_{3}^{-2}$ addition) that recirculated through the sediment in the downward direction at a pore water velocity of $\sim 0.9 \times 10^{-4} \mathrm{~m} \mathrm{~s}^{-1}$ (after Angermann et al., 2012). Artificial water was allowed to enter the chamber through a side port in the chamber wall, $\sim 2 \mathrm{~cm}$ above the water level, to ensure fast equilibration of $\mathrm{CO}_{2}$ between water and the headspace needed for respiration analysis and to prevent anoxic conditions (Figure 1b). We chose artificial water as the percolation medium to avoid uncontrolled introduction of microbial communities and organic $\mathrm{C}$ substrates or other nutrients.

We sampled the sediments from a ripple region (upper $2 \mathrm{~cm}$ ) of a lowland stream (Rheinsberger Rhin, 52 $34^{\prime} 25^{\prime \prime N} 14^{\circ} 6^{\prime} 12^{\prime \prime E}$, Brandenburg, Germany) characterized by regular sediment movement as well as intensive vertical water exchange and thereby intrusion of oxygen. The sampling area is surrounded by mixed forests and characterized by low-nutrient loading and low OM sandy sediments. After sampling, we sieved the sediment with stream water through 90- and 1000- $\mu \mathrm{m}$ meshes to remove the silt and clay as well as the coarse POM fraction. We let the resulting sediment slurries acclimate from in situ $\left(2^{\circ} \mathrm{C}\right)$ to experimental conditions in a stepwise $\left(1-1.5^{\circ} \mathrm{C} \mathrm{d} \mathrm{d}^{-1}\right)$, 2-week-long procedure while allowing percolation by artificial water. After acclimation, we mixed the organic substrates into the sediment according to our treatments and subsequently filled the resulting slurries into the 


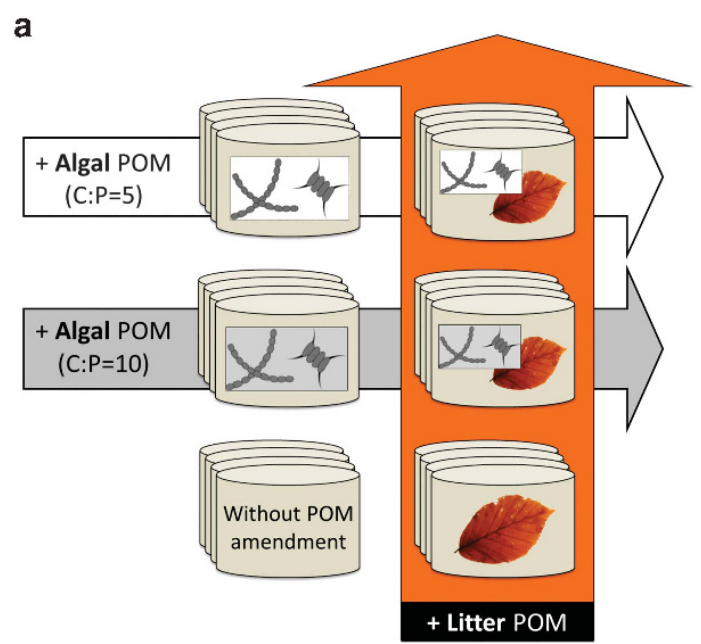

b

${ }^{13} \mathrm{C}-\mathrm{CO}_{2}$ Isotope Analyser

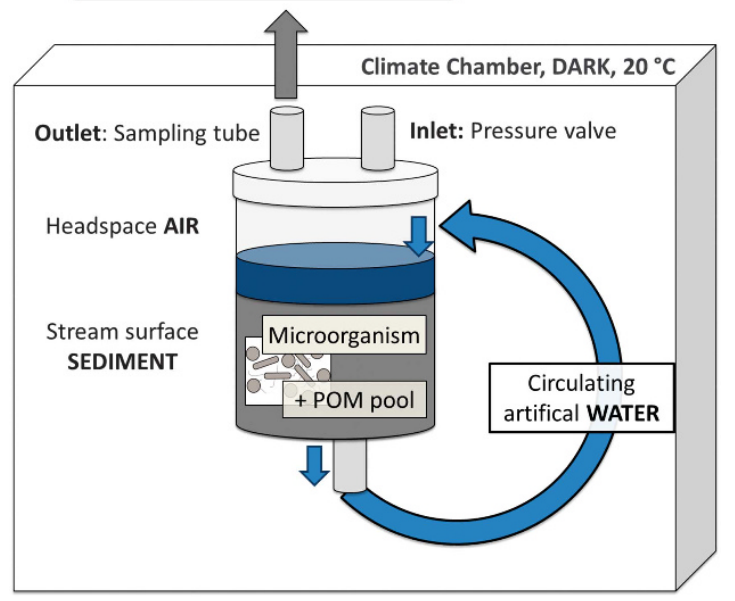

Figure 1 (a) Treatments applied on the sampled sediments with respect to organic $\mathrm{C}$ modifications. Beech litter, algae (High C:P) and algae (Low C:P) were added as single-substrate modifications (algae or beech modification) or a mixture of these was used for the mixed modifications (mixed modifications: algae+beech). (b) Experimental set-up of incubation chambers with a focus on the flow path for artificial water.

incubation cylinders (four replicates each). The slurry approach was essential to ensure equal starting conditions for all treatments with respect to the composition of the microbial community and POM treatments and is commonly used in studies interrelating environmental effects on microbial performance (for example Marotta et al., 2014; Dyksma et al., 2016).

The different sediment POM pools were generated through the combination of three ${ }^{13} \mathrm{C}$-labeled POM substrates that differed in quality with respect to chemical structure and nutrient content. These were: pre-leached beech litter (1-2 mg per g sediment dry weight, $\delta^{13} \mathrm{C}=4500 \%$ ) as a proxy for a low-quality, stream C substrate of terrestrial origin, characterized by a highly complex aromatic structure and lownutrient content (C:N:P=187:2:1); two algal substrates (6-12 $\mu \mathrm{g}$ per g sediment dry weight) as proxy for high-quality, stream C of aquatic origin. Both algal substrates differed in their $\mathrm{P}$ content and are referred to as algae HighCP (C:N:P=80:10:1, $\delta^{13} \mathrm{C}=503 \%$ ) and algae LowCP (C:N:P = 36:5:1, $\delta^{13} \mathrm{C}=488 \%$ ) throughout the manuscript. Compared with the beech litter, the two algal substrates are characterized by a less-complex molecular structure and higher nutrient content that is assumed to be easily available for microbial decomposition. A detailed description of the applied OM substrates, including their preparation, has been provided in the Supplementary Methods. We amended the sediment with these three substrates in five different ways, resulting in five treatments that differed in their substrate composition of the sediment POM (Figure 1a): sediment with algae HighCP; sediment with algae LowCP; sediment with beech litter; sediment with beech litter and algae HighCP; and sediment with beech litter and algae LowCP. In addition to our treatments, we incubated four chambers with non-amended sediment (control) and applied the same handling to the entire preparation and incubation process.

We monitored microbial C respiration by sampling the headspace $\mathrm{CO}_{2}$ every $6 \mathrm{~h}$ throughout the incubation. In addition, we sampled the water and sediment at the beginning (day 0) and the end (day 46) to obtain information on differences in the composition of the microbial decomposers, their metabolic activity (respiration and substrate specific assimilation), and nutrient consumption. During sampling, we collected the sediment in sterile falcon tubes using a laboratory spoon and the water in an Erlenmeyer flask through a port in the chambers' sidewall. For the start sample (day 0), we collected the sediment and water $\sim 6 \mathrm{~h}$ after amendment with OM substrates and filling into incubation chambers to allow settling of the initially suspended sediment particles before the sampling.

Community composition of the microbial decomposers Information on the composition of microbial decomposers was obtained through PLFA analysis from sampled sediments at days 0 and 46. PLFA are present in the membranes of all living cells and rapidly degrade to neutral lipids upon cell death (reviewed in Willers et al., 2015), hence offer sensitive and reproducible measurements for characterizing microbial communities (for example, Boschker and Middelburg, 2002; Weise et al., 2016). We extracted total lipids from $15 \mathrm{~g}$ of freezedried sediment using a well-established modified method described by Frostegard et al. (1991) and Steger et al. (2011). A detailed description on the extraction and analysis of PLFA from the sediments is given in the Supplementary Methods. The concentration of each identified microbial PLFA was corrected to the total concentration of microbial PLFA to compensate for variations resulting from PLFA extraction. We identified 15 PLFAs that occur 
in the membranes of bacteria (i15:0, a15:0, i17:0),

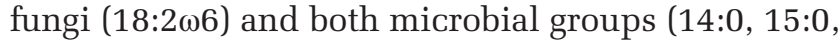

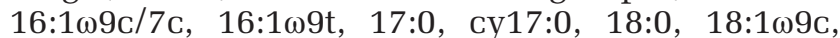

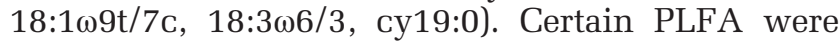
assigned to separate fungi $(18: 2 \omega 6)$ from heterotrophic bacteria (i15:0) based on previous research (Boschker and Middelburg, 2002; De Carvalho and Caramujo, 2014) to disentangle their metabolic activity with respect to $\mathrm{C}$ assimilation from the introduced substrates.

\section{Microbial C mineralization}

Microbial $\mathrm{C}$ mineralization ( $\mathrm{C}$ min), and thereby microbial activity, was measured as gaseous $\mathrm{CO}_{2}$ emitted $\left.(\text { emCO})_{2}\right)$ during a 6 hour incubation period (equation 1). Total C mineralization was calculated from the sum of water total inorganic carbon $\left(\Delta \mathrm{TIC}_{\text {Water }}\right)$ and $\mathrm{emCO}_{2}$ produced during 46 days $(\mathrm{d})$ of incubation, expressed as a percentage of sediment total organic carbon (TOC), according to equations 2 and 3 .

$$
\begin{aligned}
C \min & =\frac{\mathrm{emCO}_{2}}{\mathrm{~h}} \\
& =\frac{\left[C \mathrm{C}_{2}\right]_{\text {headspace }}^{\mathrm{t=6h}}-\left[\mathrm{CO}_{2}\right]_{\text {headspace }}^{\mathrm{t}=0 \mathrm{~h}}}{\Delta \mathrm{t}}
\end{aligned}
$$

$$
\Delta T I C=T I C_{\text {water }}^{t=\text { day } 46}-T I C_{\text {water }}^{t=\text { day } 0}
$$

Total $C \min =\frac{\left(\sum_{d=0}^{46} \frac{e m C O_{2}}{24 h}(d)+\Delta T I C\right)}{\text { sediment } T O C} \times 100$

The concentration and isotopy of $\mathrm{emCO}_{2}$ was measured every $6 \mathrm{~h}$ using an Off-Axis IntegratedCavity Output Spectroscope (Off-Axis ICOS CCIA, Los Gatos Research, CA, USA) connected to the chambers' headspace through tubes. The superscripts ' $t=6 \mathrm{~h}$ ' and ' $t=0 \mathrm{~h}$ ' represent the end and start of the incubation period. Every 12-24 h, we calibrated the instrument against an internal standard gas $\left(70 \% \mathrm{~N}_{2}, 30 \% \mathrm{O}_{2}\right.$ and $0.15 \% \mathrm{CO}_{2}$, Airliquide, Germany) and against the international standard Vienna Pee Dee Belemnite values to correct for isotope drifting, yielding a precision of $2 \%$ for $\delta^{13} \mathrm{C}$ and $1 \mathrm{ppm}$ for $\mathrm{CO}_{2}$ concentration. The detailed description of headspace $\mathrm{CO}_{2}$ analysis is provided in the Supplementary Methods. TIC was analyzed immediately after sampling according to DIN EN 1484 (DEV, H3) on a multi N/C 2100 Analyzer (Jena Analytics, Jena, Germany).

Food source elucidation of the respired $\left(\mathrm{emCO}_{2}\right)$ and microbial fixed $C$ (PLFA)

For single OM modifications, we applied a two-source mixing model approach proposed by Cheng (1996) on emCO $\mathrm{CO}_{2}$ to separate the sediment OM-derived $\mathrm{CO}_{2}$ emission $\left(\mathrm{C}_{\mathrm{SED}}\right)$ and algae-derived $\mathrm{CO}_{2}$ emission $\left(\mathrm{C}_{\mathrm{A}}\right)$ using equations 4 and 5:

$$
C_{S E D}=e m C O_{2} \times \frac{\left(\delta^{13} e m C O_{2}-\delta^{13} C_{A}\right)}{\left(\delta^{13} C_{S E D}-\delta^{13} C_{A}\right)}
$$

$C_{A}=e m C O_{2}-C_{S E D}$

For mixed OM modifications (beech and algae together), we applied a two-source mixing model approach (equations 6 and 7) to separate for sediment +algae OM-derived $\mathrm{CO}_{2}$ respiration $\left(\mathrm{C}_{\mathrm{SED}+\mathrm{A}}\right)$ and beech litter-derived $\mathrm{CO}_{2}$ respiration $\left(\mathrm{C}_{\mathrm{BEECH}}\right)$. In this approach, we treated the sediment and algal $\mathrm{C}$ as one $\mathrm{C}$ source and beech litter $\mathrm{C}$ as the second possible $\mathrm{C}$ source.

$$
\begin{aligned}
& C_{S E D+A}=e m C O_{2} \times \frac{\left(\delta^{13} e m C O_{2}-\delta^{13} C_{B E E C H}\right)}{\left(\delta^{13} C_{S E D+A}-\delta^{13} C_{B E E C H}\right)} \\
& C_{B E E C H}=e m C O_{2}-C_{S E D+A}
\end{aligned}
$$

We obtained $\delta^{13} \mathrm{emCO}$ from Keeling plot analyses of headspace $\mathrm{CO}_{2}$ (Pataki, 2003). $\delta^{13} C_{A}, \delta^{13} C_{S E D+A}$ and $\delta^{13} C_{B E E C H}$ were assumed to be equal to $\delta^{13} C$ of the POM, based on the report by Mary et al. (1992), where fractionation during microbial degradation processes was shown to be negligible.

We used the same mixing model approach on specific PLFA biomarkers to separate for sediment OM and substrate-derived $\mathrm{C}$ assimilated into the different biomarkers. We obtained $\delta^{13} C$ for each specific PLFA biomarkers after correcting using a fractionation factor of $5 \%$, which is an average according to Boschker and Middelburg (2002). Fractionation factors may vary slightly between 1 and 3\% for different PLFA biomarkers and according to environmental conditions; however, these variations are negligible because of the high enrichment in ${ }^{13} \mathrm{C}$ achieved with our tracer approach.

\section{Nutrient analysis}

Prior to analysis, we freeze-dried and grinded the sediments sampled at days 0 and 46 . For TP analysis, we applied the ammonium molybdate spectrometric method (DIN EN ISO 6878 2004). Determination of total organic carbon (TOC) and total nitrogen were performed according to DIN EN 14841997 using an Elementar Vario EL cube (Elementar Analysensysteme $\mathrm{GmbH}$, Hanau, Germany).

Dissolved nutrients were analyzed from water sampled at day 0 and 46 after filtration through a $0.45 \mu \mathrm{m}$ cellulose acetate filter (Sartorius Stedim Biotech GmbH, Goettingen, Germany). Soluble reactive phosphorus was determined photometrically on a UV/VIS-Photometer CARY 1E (VARIAN, Darmstadt, Germany) according to DIN EN ISO 11732 modified after Murphy and Riley (1962). Dissolved inorganic nitrogen (sum of $\mathrm{NO}_{3}^{2-}$ and $\mathrm{NH}_{4}^{+}$) was analyzed according to DIN EN 1189 on a CFAPhotometer Skalar SAN (Skalar Analytical B.V., 
Breda, The Netherlands) and dissolved organic carbon according to DIN EN 1484 on a multi N/C 3100 Analyzer (Jena Analytics).

\section{Statistical analysis}

To evaluate and visualize changes in the composition of microbial communities according to our treatments, we performed a non-metric dimensional scaling (NMDS, three dimensions) ordination and a non-parametric multivariate analysis of variance (PERMANOVA) on computed pairwise Bray-Curtis dissimilarities on proportional lipid data (after Hall et al., 2010). We also performed a principal component analysis (PCA) to identify important fatty acids that showed different results between our POM treatments at day 46. PCA was performed on a correlation matrix generated from proportional lipid data and the ratio of bacterial to fungal PLFA

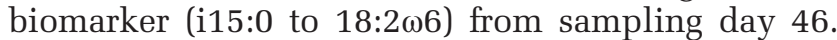
We further applied non-parametric Kruskal-Wallis rank sum tests with subsequent post hoc Dunn's tests with Bonferroni correction to test for treatment effects $(n=3-4)$ with regard to the consumption of nutrients, assimilation of beech $\mathrm{C}$ into microbial PLFA, and changes in fungal $(18: 2 \omega 6)$ and bacterial (i15:0) group-specific PLFA biomarkers. We determined the significances of differences between treatments for cumulative respiration of beechderived $\mathrm{C}$ throughout the final incubation period $(30 \leqslant t \leqslant 46)$ by computing a linear mixed-effects model. The fixed structure was set as the interaction for treatment+control (6 levels) and sampling time (11 levels), and for the random structure, we allowed different intercepts for each replicate. Each linear mixed-effects model was followed by a model validation to check the residuals for normal distribution and homogeneity of variances. Statistical significance of the interaction was tested using a likelihood-ratio test by comparing the model with and without the interaction. When the interaction was significant, we analyzed each sampling time individually. The linear mixed-effects models were followed by the conservative Turkey's post hoc test to test significant differences between treatments. Further, we performed single linear regression analysis to relate $\mathrm{C}$ turnover to the ratio of group-specific biomarkers. All statistical analyses were performed in the statistic software $R$ using packages dunn.test, MASS, multcomp, nmle, vegan and psych at a significance level of $P \leqslant 0.05$ (Team R, 2010).

\section{Results}

Sediment POM modifications resulted in five POM pools (treatments) that differ in their composition of labile and refractory substrates (Figure 1a) and nutrient content (Table 1).

\section{Composition of microbial decomposers in relation to POM pools}

NMDS ordination based on Bray-Curtis dissimilarity on proportional PLFA data (Figure 2a) showed a significant shift in the composition of all the identified PLFA after our treatment (PERMANOVA, Pseudo-F $=2.901, P=0.003)$. Therein, the PLFA composition significantly differed between POM pools at the end of the incubation period (day 46) and was related to both the presence of algae as well as beech litter substrates within POM pools (PERMANOVA, Pseudo-F $=4.237, P=0.003$ ). In addition, PCA on proportional PLFA data (Figure 2b) indicated that variation in the ratio of the abundance of fungi $(18: 2 \omega 6)$ to heterotrophic bacteria (i15:0) explains $42.4 \%$ of the observed interrelation between POM pools and PLFA composition. Thus, the abundance of fungal PLFA (Supplementary Figure S1b) increased in the presence of beech litter (Kruskal-Wallis, $\chi_{(5)}^{2}=15.663, P=0.01$ ), which was most pronounced for sediments incubated without algae (Beech, Dunn's test, $P=0.01$ ) and was independent of algal C:P stoichiometry in sediments amended with beech (Beech+Algae, Dunn's test, $P=1$ ). Further, PCA revealed that another $22.5 \%$ of the variation in PLFA data relates to the abundance of bacterial-specific PLFA i15:0 but was not related to our POM modifications (Supplementary Figure S1a, Kruskal-Wallis on i15:0, $\chi_{(5)}^{2}=8.666, P=0.12$ ).

Mineralization of $C$ substrates in relation to POM pools Figure 3 and Supplementary Figure S2 show the resulting changes in $\mathrm{C}$ mineralization after our 

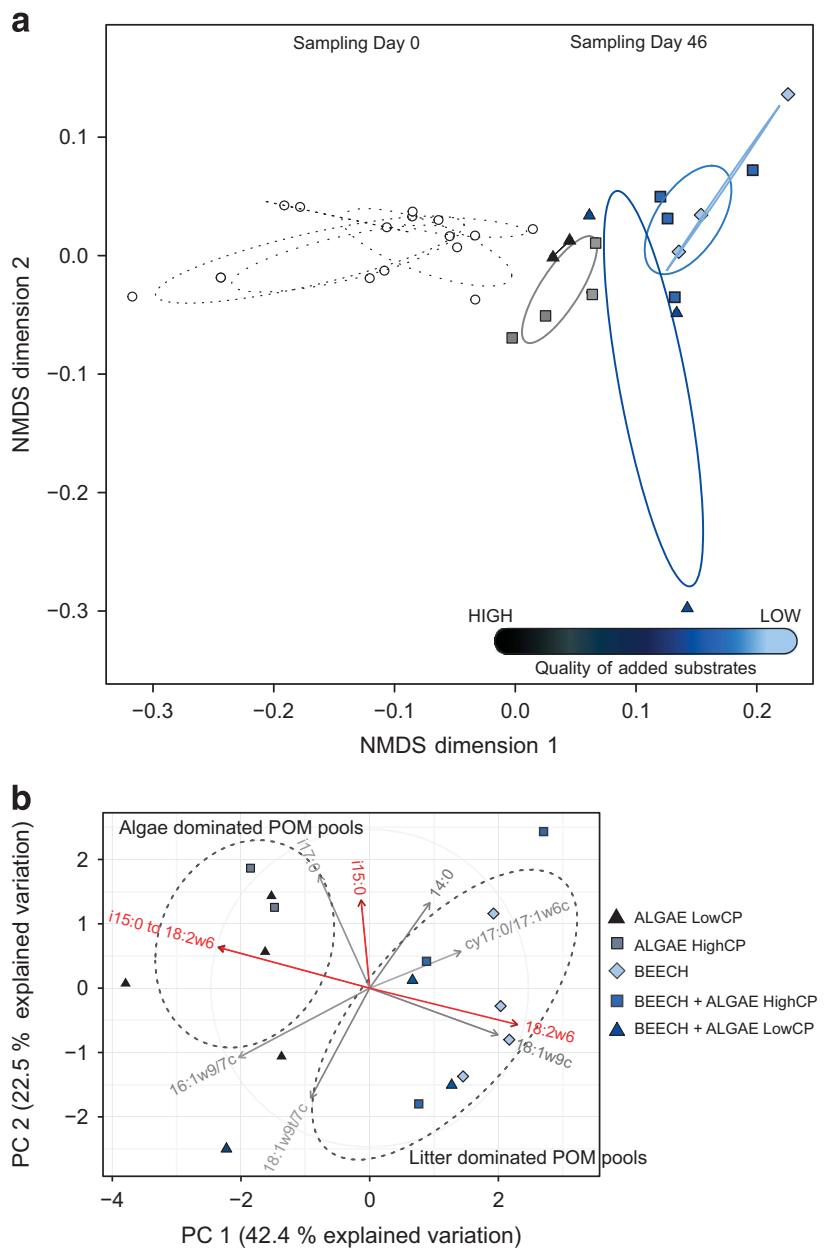

Figure 2 (a) Non-metric multidimensional scaling ordination based on Bray-Curtis dissimilarity on PLFA data, Kruskal's stress $=0.02$. Open dots (dashed ellipses) and colored squares or triangles (solid ellipses) separate sediment samples taken $6 \mathrm{~h}$ and 46 days after organic matter modifications, respectively. Colors separate the samples according to the modification: black=algae $($ LowCP); gray=algae $($ HighCP $)$; dark blue=algae $($ LowCP $)$ with beech litter; blue =algae (HighCP) with beech litter; light blue = beech litter. Ellipses represent 95\% intervals around centroids for each treatment. (b) Principal component analysis of fatty-acid profiles of sediments sampled at day 46 reveal a main shift in PLFA biomarkers for heterotrophic bacteria (i15:0) versus fungi (18:2 $\omega 6)$ based on POM pool quality.

POM modifications. Total C mineralization was significantly related to the composition of POM pools (Supplementary Figure S2a, Kruskal-Wallis, $\left.\chi_{(3)}^{2}=11.514, P=0.01\right)$. Throughout the final incubation period (day 30-46), C mineralization patterns in sediments amended with algal substrates (Supplementary Figure S2a) were significantly related to algal nutrient stoichiometry (Dunn's test, $P<0.01)$. Further, C mineralization was significantly related to algae C:P stoichiometry in sediments amended with beech litter (KruskalWallis, $\left.\chi_{(2)}^{2}=7, \quad P=0.03\right)$. Significantly higher mineralization rates were observed for POM pools of beech litter and P-enriched algae (LowCP, Dunn's test, $P=0.018$ ).

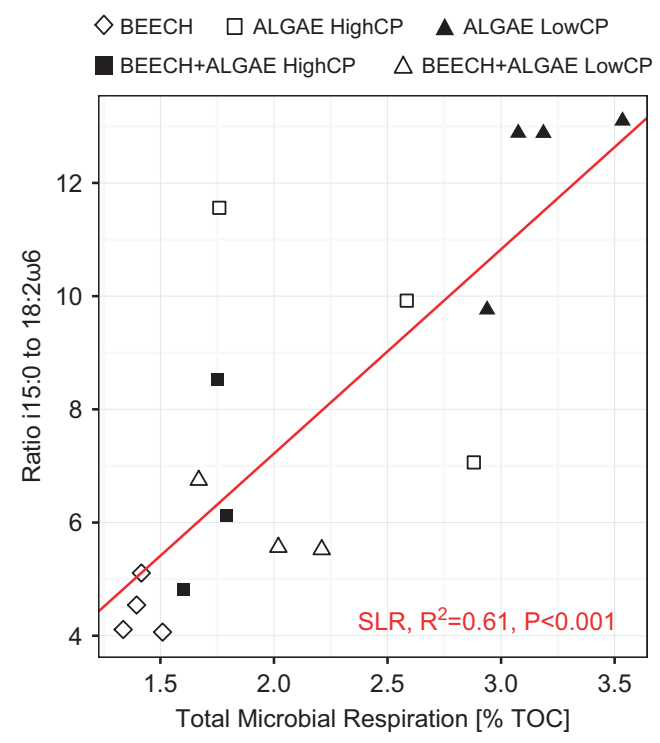

Figure 3 Community dynamics versus microbial respiration.

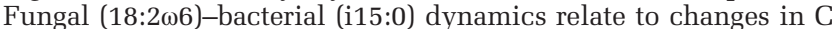
mineralization, where higher turnover rates were observed in the sediments with OM pools of higher quality.

Stable-isotope analysis of the respired $\mathrm{CO}_{2}$ provides information on $\mathrm{OM}$ substrates metabolized by the microbial community. Unfortunately, we lost the isotope data for the first 29 days of incubation owing to technical problems. However, the available data indicate a general increase in the mineralization of beech litter POM and a decrease in the mineralization of algal POM throughout the incubation period (data not shown).

Figure 4 gives an overview of the effect of algal POM on the mineralization of beech litter. Thus, two-end member mixing model analysis of emCO $\mathrm{O}_{2}$ revealed a significant relation between $\mathrm{POM}$ pools and the proportion of beech-derived $\mathrm{C}$ in mineralized $\mathrm{C}$ (Figure 4b, Kruskal-Wallis, $\chi^{2}{ }_{(2)}=7.86, P=0.01$ ). Even so, the stimulative effect of algae $\mathrm{OM}$ on total $\mathrm{C}$ mineralization resulted in a higher amount of beech $\mathrm{C}$ respired throughout incubation (Figure 4a, linear mixed-effects model, LowCP: $P=0.026$, High CP: $P=0.058$ ), which was unrelated to algal nutrient stoichiometry.

The observed differences in C mineralization were significantly related to fungal-bacterial ratios (Figure 3; single linear regression, $R^{2}=0.61, P<0.001$ ), that is, higher $\mathrm{C}$ mineralization, as measured for sediments with a higher ratio of bacterial to fungal PLFA, which was the case when algal POM, in particular that of high nutrient content, was added.

Effect of algal POM on the assimilation of beech litter by fungi and bacteria

${ }^{13} \mathrm{C}$ isotope analysis of phospholipids provides information on the substrates metabolized by fungi and bacteria in relation to our POM treatments. Figure 5 provides an overview of the ${ }^{13} \mathrm{C}$ isotope enrichment $\left(\delta^{13} \mathrm{C}\right)$ in all the identified PLFA at day 
46, which was for all treatments up to 10 -fold higher in fungal- $(18: 2 \omega 6)$ then in bacterial- and unspecific PLFA biomarkers. Incubation of sediments with
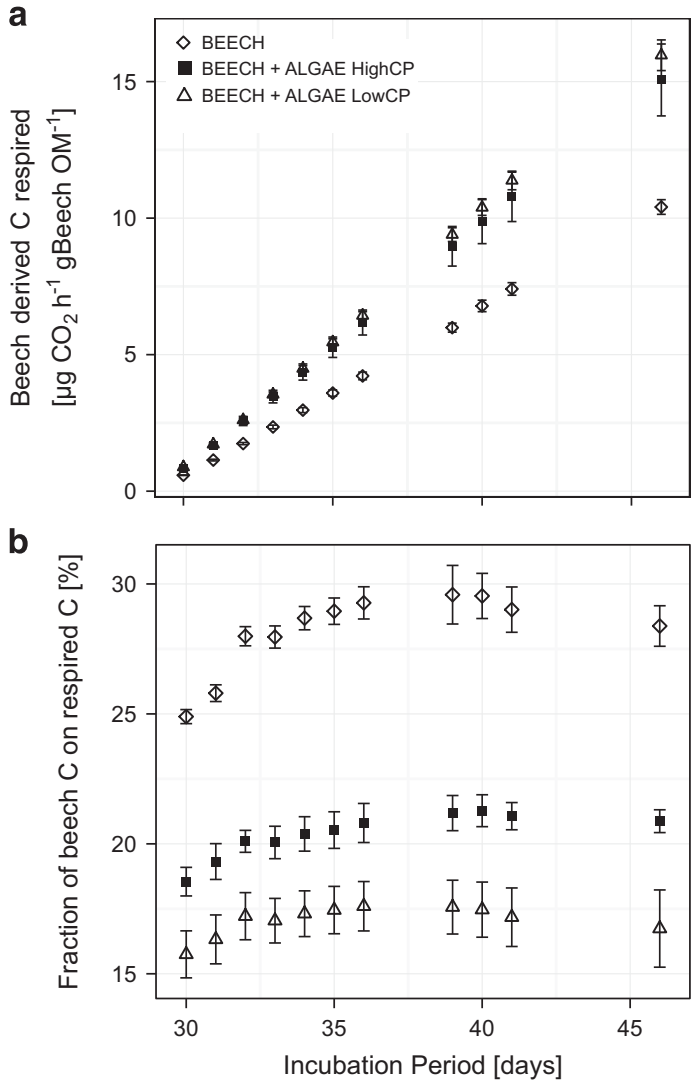

Figure 4 Effect of algal OM on (a) overall and (b) fractional beech $\mathrm{C}$ turnover. Addition of algal $\mathrm{OM}$ high in $\mathrm{P}$ stimulated overall microbial respiration of beech-derived $\mathrm{C}$ but decreased the fractional utilization of beech C. Data are shown for the incubation period from day 30 to day 46. Data are presented as the mean of replicates $(n=3-4)$ with s.d.

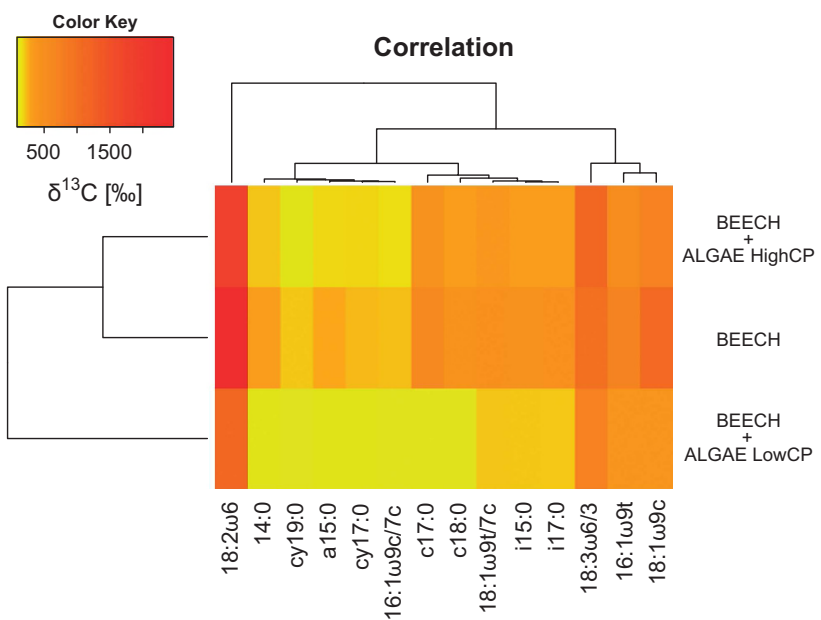

Figure 5 Overview of $\delta^{13} \mathrm{C}$ enrichment in microbial PLFA for all OM modifications including beech OM. Similar stable-isotope enrichment among PLFA is observed for OM modifications with only beech OM and in mixture with highCP algae OM. Data are presented as mean of replicates $(n=3-4)$.
POM pools of beech and beech+algae HighCP resulted in similar ${ }^{13} \mathrm{C}$ isotope enrichment in PLFA.

Total amount of beech C assimilated into PLFA specific for heterotrophic bacteria (i15:0) was related to the composition of POM pools (Figure 6, KruskalWallis, $\left.\chi_{(2)}^{2}=5.6, P=0.06\right)$, more precisely stimulated in presence of High C:P algae (Dunn's test, $P=0.04$ ). In contrast, the amount of beech $\mathrm{C}$ assimilated into fungal PLFA was independent of algal presence (Kruskal-Wallis, $\chi_{(2)}^{2}=3.84, P=0.15$ ).

\section{Consumption of dissolved inorganic and organic nutrients}

The consumption of soluble reactive phosphorus (Kruskal-Wallis, $\chi_{(5)}^{2}=1.274, P=0.94$ ), dissolved inorganic nitrogen (Kruskal-Wallis, $\chi^{2}{ }_{(5)}=9.016, P=0.11$ ) and dissolved organic carbon (Kruskal-Wallis, $\left.\chi^{2}{ }_{(5)}=7.179, \quad P=0.21\right)$ was similar between all the treatments, except for lower consumption of dissolved inorganic nitrogen in the sediments modified using algae HighCP. Dissolved inorganic nitrogen was limiting at the end of incubation. For data, see Supplementary Table S1.

\section{Discussion}

As expected, algae OM greatly stimulates microbial decomposition of terrigenous POM in aquatic ecosystems (Danger et al., 2013; Ward et al., 2016). Nevertheless, this study showed that microbial fungal and bacterial decomposers respond differently to substrate variations in POM pools and thus contributes to a better understanding of the role of microbial decomposers in terrestrial-aquatic C cycling.

Pronounced contrasts in substrate quality drive fungalbacterial occurrence within the degrader communities With regard to their distinct quality, algal and leaf litter are considered to differ in their availability to microbial decomposers (for example, Marcarelli et al., 2011; Attermeyer et al., 2014). This is reflected by the measured differences in the C-respiration rates observed for sediments amended with algae or beech litter (Figure 3 and S2a).

Thus, the interrelation between POM quality and bacterial to fungal occurrence observed in this study agree with the reported distinct metabolic capabilities of these organisms to break down substrates of different qualities (Rinnan and Bååth, 2009). Beech litter within POM pools favored the occurrence of fungi (Figure 3 and Supplementary Figure S1b), confirming that they dominate microbial communities when growing on refractory, nutrient-poor OM (Hieber and Gessner, 2002). However, amendments with algal $\mathrm{OM}$ favored the dominance of bacteria over fungi, denoting their competitive colonization and turnover of these high-quality substrates (for example, Bardgett et al., 1999; Fontaine et al., 2003). 


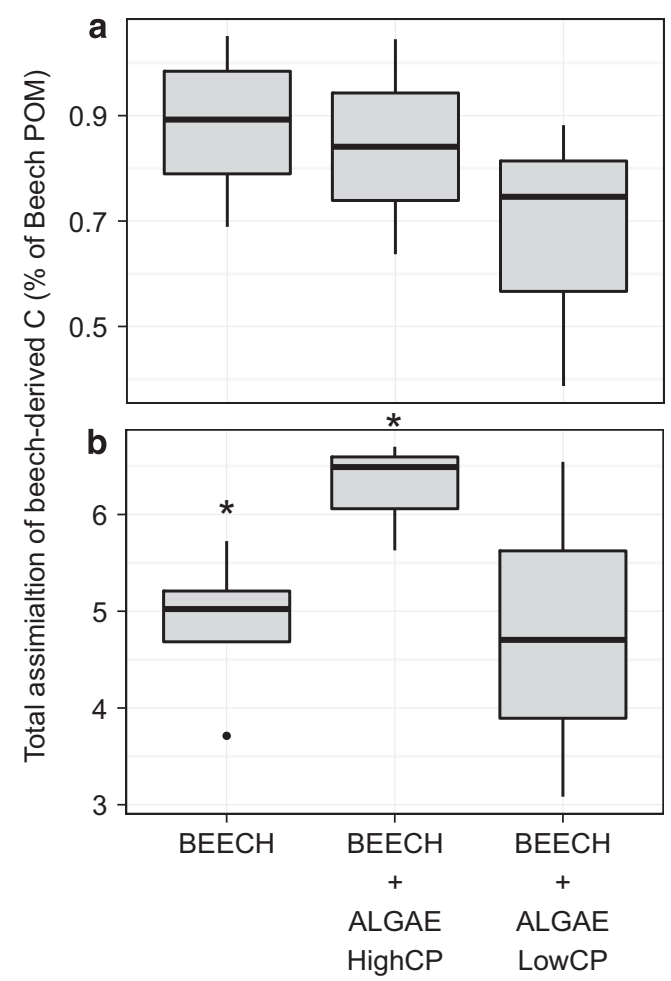

Figure 6 Amount of beech-derived C fixed into microbial PLFA after 46 days of incubation for (a) fungal PLFA (18:2w6) and (b) bacterial PLFA (sum of all bacterial PLFA) given in \% of beech used. The presence of algae HighCP enabled a 1.5-2\% assimilation of beech C into bacterial PLFA but not into fungal PLFA. Asterisk boxes indicate significant differences between the marked treatments.

In addition, the lower abundance of fungal lipids in sediments amended with algal POM (Supplementary Figure S1b) indicates bacterial antagonism against fungi (Wargo et al., 2006 and references therein), which was shown to be stimulated in the presence of high-quality OM (Mille-Lindblom et al., 2006) such as our applied algal substrates.

Bacterial to fungal ratios did not differ between the algal P treatments (Figure 3), but NMDS on proportional data (Figure 2a) indicates a different composition of bacterial and fungal PLFA between the two algal C:P treatments. This mismatch between the results of the two analyses implies that the quantity of labile and refractory substrates within POM pools determines the ratio between fungi and bacteria, whereas other environmental factors such as the C:P ratio of the labile substrate might primarily affect the species composition within each group.

\section{Contribution of aquatic fungi and bacteria to} terrigenous $C$ turnover varies between POM pools

In accordance with previous findings (for example, Danger et al., 2013), algae POM stimulated the decomposition of beech litter (Figure 4a). However, our results support that the contribution fungi and bacteria to beech decomposition is likely not affected by algal POM in the same manner.
The more pronounced ${ }^{13} \mathrm{C}$ enrichment in the fungal compared with that in bacterial specific phospholipids (Figure 5) implies that fungi primary degrade beech litter, yet, fungal abundance was reduced in presence of algal OM. In result, a stimulated decomposition of beech litter by algal OM (Figure 4a) related to a more pronounced dominance of bacteria within the degrader communities (Figure 3) and thus resulted in an increased contribution of bacteria to beech $\mathrm{C}$ processing.

Bacterial abundance varied only slightly with our POM modification, implying that the additional C substrate was primarily expended for energy required for respiration, which is also supported by the observed less pronounced effect of algal POM on the assimilation of beech $\mathrm{C}$ into microbial lipids (Figure 6). In addition, algal POM did not increase the use of beech $\mathrm{C}$ in preference over other C substrates by microbial decomposers (Figure 4b), thus confirming that high-quality POM stimulated the contribution of bacteria to leaf breakdown through an increase in their metabolic activity rather than through affecting their abundance or substrate preference.

Nutrient availability modifies the metabolic performance of bacteria in terrigenous $C$ turnover The availability of nitrogen $(\mathrm{N})$ and phosphorus (P) frequently controls ecological processes (Elser et al., 2007) such as litter decomposition (Gulis and Suberkropp, 2003; Rier et al., 2014). In the present study, $\mathrm{N}$ and $\mathrm{P}$ were almost exclusively provided in particulate form through algal and/or beech litter substrates, whereas the pool of external inorganic $\mathrm{N}$ and $\mathrm{P}$ remained to be small to limiting (Supplementary Table S1). In addition, the C to nutrient stoichiometry of our applied leaf litter by far exceeds the nutrient demands of fungi and bacteria in contrast to the applied algal substrates (reviewed in Danger et al., 2016). Thus, we assumed that the additional $\mathrm{N}$ and $\mathrm{P}$ provided with the algal substrates determine whether the beech-derived $\mathrm{C}$ is assimilated into microbial biomass or mineralized to $\mathrm{CO}_{2}$.

In this respect, mineralization of beech litter was stimulated in presence of nutrient-rich, algal POM (Figure 4a), yet independent of algal C:P stoichiometry, implying that the quantity of algal POM primarily relates to the extent to which these labile $\mathrm{C}$ compounds stimulate the decomposition of refractory $\mathrm{C}$ substrates. With regard to the assimilation of beech C into biomass (Figure 6), we also did not observe a significant response to our algal treatments for fungal lipids, but a slight response for bacterial lipids was observed, confirming that both groups of organisms may acquire different amounts (Güsewell and Gessner, 2009) and pools of nutrients during litter decomposition. That is, fungi may fulfill their energy and nutrient demand directly from the decomposition of litter (Suberkropp and Chauvet, 1995; Gadd, 2006). In contrast, our results indicate 
that the bacterial assimilation of low-nutrient, refractory $\mathrm{C}$ relies on additional nutrient pools, in particular with respect to $\mathrm{P}$ (Figure 6). This is further supported by the stronger variation in ${ }^{13} \mathrm{C}$ in bacterial than fungal specific PLFA with our POM treatment indicating that bacteria respond more sensitive to our algae treatments than fungi (Figure 5). As previously noted, the composition of POM pools with different algal C:P substrates resulted in distinct compositions of microbial decomposers (NMDS, Figure 2a). Thus, the higher amount of beech $\mathrm{C}$ assimilated into bacterial PLFA in the presence of high C:P algae may have resulted from a shift in the microbial community composition toward species that have a lower $\mathrm{P}$ demand and are more competitive in the assimilation of litter compounds.

\section{Conclusion}

This study greatly improves our understanding of the effect of labile high-quality substrates on the fate of terrigenous $\mathrm{OM}$ in aquatic environments. We showed that the abundance of fungi and bacteria within degrader communities and their performance in metabolizing terrigenous $\mathrm{OM}$ are not intimately linked to each other, but largely depend on the composition of OM pools with respect to substrate quality. Clearly, the quantity of labile and refractory substrates determined the dominance of fungi and bacteria within the degrader communities and thereby the turnover of terrigenous C. However, the presence of specific environmental parameters such as $\mathrm{P}$ availability may also determine whether terrigenous substrates are assimilated and thereby transported into other trophic levels.

Our results suggest that aquatic fungi contribute to terrigenous $\mathrm{C}$ turnover by providing these $\mathrm{C}$ substrates for the microbial loop, whereas aquatic bacteria determine the amount of terrigenous $\mathrm{C}$ to be potentially recycled into the terrestrial environment through its emission into the atmosphere in the form of $\mathrm{CO}_{2}$. However, given the large variety of $\mathrm{POM}$ pools in aquatic ecosystems and the few studies that exist on particulate $\mathrm{C}$ turnover, our results highlight the need for more sophisticated research to fully understand the contribution of fungi and bacteria to aquatic turnover of terrigenous $\mathrm{C}$ in relation to environmental conditions. Further, this study points out that the effects on both metabolic processes, assimilation and mineralization, have to be considered to fully understand these relations. Thus, the combinations of microbial and biogeochemical analyses with stable isotopes facilitated a more detailed observation of the underlying processes, and we highly recommend their application in further research.

\section{Conflict of Interest}

The authors declare no conflict of interest.

\section{Acknowledgements}

We thank Angela Krueger for her help during extraction of PLFAs and the technicians from the Department of Chemical Analytics and Biogeochemistry (IGB) for their support in chemical analyses. Moreover, we would like to thank Amanda Cheng for laboratory assistance and Pascal Bodmer for help with the statistical analysis. We thank Thomas Mehner and the participants of the workshop 'Scientific Writing' at the IGB for helpful discussions on an earlier version of the manuscript. In particular, we thank Hans-Peter Grossart for his fruitful comments on the final stage of the manuscript and Editage Cactus Communications for English proof reading. The study was conducted within the DFG-project (MU 1464/51 and PR 710/5-1), which was financially supported by the German Research Foundation (DFG, Bonn).

\section{References}

Angermann L, Krause S, Lewandowski J. (2012). Application of heat pulse injections for investigating shallow hyporheic flow in a lowland river. Water Resour Res 48: 1-16.

Attermeyer K, Hornick T, Kayler ZE, Bahr A, Zwirnmann E, Grossart HP et al. (2014). Enhanced bacterial decomposition with increasing addition of autochthonous to allochthonous carbon without any effect on bacterial community composition. Biogeosciences 11: 1479-1489.

Attermeyer K, Premke K, Hornick T, Hilt S, Grossart HP. (2013). Ecosystem-level studies of terrestrial carbon reveal contrasting bacterial metabolism in different aquatic habitats. Ecology 94: 2754-2766.

Baldy V, Gessner MO, Chauvet E. (1995). Bacteria, fungi and the breakdown of leaf litter in a large river. Oikos 74: 93-102.

Bardgett RD, Freeman C, Ostle NJ. (2008). Microbial contributions to climate change through carbon cycle feedbacks. ISME J 2: 805-814.

Bardgett RD, Kandeler E, Tscherko D, Hobbs PJ, Bezemer TM, Jones TH et al. (1999). Below-ground microbial community development in a high temperature world. Oikos 85 : 193-203.

Battin TJ, Besemer K, Bengtsson MM, Romani AM, Packmann AI. (2016). The ecology and biogeochemistry of stream biofilms. Nat Rev Microbiol 14: 251-263.

Battin TJ, Kaplan LA, Findlay S, Hopkinson CS, Marti E, Packman AI et al. (2008). Biophysical controls on organic carbon fluxes in fluvial networks. Nat Geosci 2: 595 .

Boschker HTS, Middelburg JJ. (2002). Stable isotopes and biomarkers in microbial ecology. Fems Micriobiol Ecol 40: 85-95.

Brandstätter C, Keiblinger K, Wanek W, ZechmeisterBoltenstern S. (2013). A closeup study of early beech litter decomposition: Potential drivers and microbial interactions on a changing substrate. Plant Soil 371: 139-154.

De Carvalho CCCR, Caramujo MJ. (2014). Fatty acids as a tool to understand microbial diversity and their role in food webs of mediterranean temporary ponds. Molecules 19: 5570-5598. 
Cheng W. (1996). Measurement of rhizosphere respiration and organic matter decomposition using natural 13C. Plant Soil 183: 263-268.

Cole JJ, Prairie YT, Caraco NF, McDowell WH, Tranvik LJ, Striegl RG et al. (2007). Plumbing the global carbon cycle: Integrating inland waters into the terrestrial carbon budget. Ecosystems 10: 171-184.

Comte J, del Giorgio PA. (2011). Composition influences the pathway but not the outcome of the metabolic response of bacterioplankton to resource shifts. PLoS One 6: e25266.

Danger M, Cornut J, Chauvet E, Chavez P, Elger A, Lecerf A. (2013). Benthic algae stimulate leaf litter decomposition in detritus-based headwater streams: a case of aquatic priming effect? Ecology 94: 1604-1613.

Danger M, Gessner MO, Bärlocher F. (2016). Ecological stoichiometry of aquatic fungi: current knowledge and perspectives. Fungal Ecol 19: 100-111.

Dyksma S, Bischof K, Fuchs BM, Hoffmann K, Meier D, Meyerdierks A et al. (2016). Ubiquitous Gammaproteobacteria dominate dark carbon fixation in coastal sediments. ISME J 1-15.

Elser JJ, Bracken MES, Cleland EE, Gruner DS, Harpole WS, Hillebrand $\mathrm{H}$ et al. (2007). Global analysis of nitrogen and phosphorus limitation of primary producers in freshwater, marine and terrestrial ecosystems. Ecol Lett 10: 1135-1142.

Findlay S, Tank J, Dye S, Valett HM, Mulholland PJ, McDowell WH et al. (2002). A cross-system comparison of bacterial and fungal biomass in detritus pools of headwater streams. Microb Ecol 43: 55-66.

Fisher SG, Likens GE. (1973). Energy flow in bear brook, New Hampshire: an integrative approach to stream ecosystem metabolism. Ecol Monogr 43: 421-439.

Fontaine S, Mariotti A, Abbadie L. (2003). The priming effect of organic matter: a question of microbial competition? Soil Biol Biochem 35: 837-843.

Frostegard A, Tunlid A, Baath E. (1991). Microbial biomass measured as total lipid phosphate in soils of different organic content. J Microbiol Methods 14: 151-163.

Gessner MO, Gulis V, Kuehn K a, Chauvet E, Suberkropp K (2007). Fungal decomposers of plant litter in aquatic ecosystems. Environ Microb Relationships 4: 301-324.

De Graaff MA, Classen AT, Castro HF, Schadt CW. (2010). Labile soil carbon inputs mediate the soil microbial community composition and plant residue decomposition rates. New Phytol 188: 1055-1064.

Gadd GM. (2006). Fungi in biogeochemical cycles Vol. 24. Cambridge University Press: Cambridge, pp 404-435.

Gulis V, Suberkropp K. (2003). Leaf litter decomposition and microbial activity in nutrient-enriched and unaltered reaches of a headwater stream. Freshw Biol 48: 123-134.

Güsewell S, Gessner MO. (2009). N:P ratios influence litter decomposition and colonization by fungi and bacteria in microcosms. Funct Ecol 23: 211-219.

Hall EK, Singer GA, Kainz MJ, Lennon JT. (2010). Evidence for a temperature acclimation mechanism in bacteria: an empirical test of a membrane-mediated trade-off. Funct Ecol 24: 898-908.

Hieber M, Gessner MO. (2002). Contribution of stream detrivores, fungi, and bacteria to leaf breakdown based on biomass estimates. Ecology 83: 1026-1038.

Kleber M, Nico PS, Plante A, Filley T, Kramer M, Swanston C et al. (2011). Old and stable soil organic matter is not necessarily chemically recalcitrant: Implications for modeling concepts and temperature sensitivity. Glob Chang Biol 17: 1097-1107.

Krauss G-J, Solé M, Krauss G, Schlosser D, Wesenberg D, Bärlocher F. (2011). Fungi in freshwaters: Ecology, physiology and biochemical potential. FEMS Microbiol Rev 35: 620-651.

Kuehn KA, Francoeur SN, Findlay RH, Neely RK. (2014). Priming in the microbial landscape: Periphytic algal stimulation of litter-associated microbial decomposers. Ecology 95: 749-762.

Lau DCP, Leung KMY, Dudgeon D. (2008). Experimental dietary manipulations for determining the relative importance of allochthonous and autochthonous food resources in tropical streams. Freshw Biol 53: 139-147.

Lehman JT. (1980). Release and cycling of nutrients between planktonic algae and herbivores. Limnol Oceanogr 25: 620-632.

Marcarelli AM, Baxter CV, Mineau MM, Hall RO. (2011). Quantity and quality: Unifying food web and ecosystem perspectives on the role of resource subsidies in freshwaters. Ecology 92: 1215-1225.

Mary B, Mariotti A, Morel JL. (1992). Use of C-13 variations at natural abundance for studying the biodegradation of root mucilage, roots and glucose in soil. Soil Biol Biochem 24: 1065-1072.

Marotta H, Pinho L, Gudasz C. (2014). Greenhouse gas production in low-latitude lake sediments responds strongly to warming. Nat Clim Chang 4: 11-14.

McGroddy ME, Daufresne T, Hedin OL. (2004). Scaling of C : N : P stoichiometry in forests worldwide: implications of terrestrial redfield- type ratios. Ecology 85: 2390-2401.

Meidute S, Demoling F, Bååth E. (2008). Antagonistic and synergistic effects of fungal and bacterial growth in soil after adding different carbon and nitrogen sources. Soil Biol Biochem 40: 2334-2343.

Mille-Lindblom C, Fischer H, Tranvik LJ. (2006). Antagonism between bacteria and fungi: Substrate competition and a possible tradeoff between fungal growth and tolerance towards bacteria. Oikos 113: 233-242.

Mille-Lindblom C, Tranvik LJ. (2003). Antagonism between bacteria and fungi on decomposing aquatic plant litter. Microb Ecol 45: 173-182.

Murphy J, Riley JP. (1962). A modified single solution method for the determination of phosphate in natural waters. Anal Chim Acta 27: 31-36.

Neufeld JD, Wagner M, Murrell JC. (2007). Who eats what, where and when? Isotope-labelling experiments are coming of age. ISME J 1: 103-110.

Pataki DE. (2003). The application and interpretation of Keeling plots in terrestrial carbon cycle research. Global Biogeochem Cycles 17: 1022.

Rier ST, Shirvinski JM, Kinek KC. (2014). In situ light and phosphorus manipulations reveal potential role of biofilm algae in enhancing enzyme-mediated decomposition of organic matter in streams. Freshw Biol 59: 1039-1051.

Rinnan R, Bååth E. (2009). Differential utilization of carbon substrates by bacteria and fungi in tundra soil. Appl Environ Microbiol 75: 3611-3620.

Rousk J, Bååth E. (2007). Fungal and bacterial growth in soil with plant materials of different $\mathrm{C} / \mathrm{N}$ ratios. FEMS Microbiol Ecol 62: 258-267.

Rousk J, Bengtson P. (2014). Microbial regulation of global biogeochemical cycles. Front Microbiol 79: 4031-4040.

Schneider T, Keiblinger KM, Schmid E, SterflingerGleixner K, Ellersdorfer G, Roschitzki B et al. (2012). 
Who is who in litter decomposition? Metaproteomics reveals major microbial players and their biogeochemical functions. ISME J 6: 1749-1762.

Steger K, Premke K, Gudasz C, Sundh I, Tranvik LJ. (2011). Microbial biomass and community composition in boreal lake sediments. Limnol Oceanogr 56: 725-733.

Strickland MS, Lauber C, Fierer N, Bradford MA. (2009). Testing the functional significance of microbial community composition. Ecology 90: 441-451.

Suberkropp K, Chauvet E. (1995). Regulation of leaf breakdown by fungi in streams: influences of water chemistry. Ecology 76: 1433-1445.

Tank J, Rosi-Marshall E, Griffiths NA, Entrekin SA, Stephen ML. (2010). A review of allochthonous organic matter dynamics and metabolism in streams. J North Am Benthol Soc 29: 118-146.

Team R (2010), R Development Core Team 2010. $R$ A Lang Environ Stat Comput http://www.mendeley. $\mathrm{com} /$ research/r-language-environment-statistical-computing96//npapers2://publication/uuid/A1207DAB-22D3-4A0482FB-D4DD5AD57C28.

Ward ND, Bianchi TS, Sawakuchi HO, Gagne-Maynard W, Cunha AC, Brito DC et al. (2016). The reactivity of plant-derived organic matter and the potential importance of priming effects along the lower Amazon River. J Geophys Res Biogeosci 121: 1522-1539.

Ward ND, Keil RG, Medeiros PM, Brito DC, Cunha AC, Dittmar $\mathrm{T}$ et al. (2013). Degradation of terrestrially derived macromolecules in the Amazon River. Nat Geosci 6: 530-533.

Wargo MJ, Hogan DA. (2006). Fungal-bacterial interactions: a mixed bag of mingling microbes. Curr Opin Microbiol 9: 359-364.

Weise L, Ulrich A, Moreano M, Gessler A, Kayler ZE, Steger K et al. (2016). Water level changes affect carbon turnover and microbial community composition in lake sediments. FEMS Microbiol Ecol 92: fiw035.

Willers C, Jansen van Rensburg P, Claassens S. (2015). Phospholipid fatty acid profiling of microbial communities - a review of interpretations and recent applications. J Appl Microbiol 119: 1207-1218.

(1) (2) (2) This work is licensed under a Creative Commons Attribution-NonCommercialShareAlike 4.0 International License. The images or other third party material in this article are included in the article's Creative Commons license, unless indicated otherwise in the credit line; if the material is not included under the Creative Commons license, users will need to obtain permission from the license holder to reproduce the material. To view a copy of this license, visit http://creativecommons.org/ licenses/by-nc-sa/4.0/

Supplementary Information accompanies this paper on The ISME Journal website (http://www.nature.com/ismej) 